\title{
O particular e o universal na poética de Carlos Drummond de Andrade
}

\author{
The particular and the universal in the poetics of Carlos Drummond de Andrade
}

El particular y el universal en la poética de Carlos Drummond de Andrade

\author{
José Wellington Dias Soares ${ }^{\circ}$
}

Universidade Estadual do Ceará, Fortaleza, CE, Brasil.

$\diamond$

\begin{abstract}
RESUMO
Nosso objetivo é analisar os elementos poéticos de Carlos Drummond de Andrade, como enriquecedores da vida humana nos seus aspectos singulares, particulares e universais. Essas categorias serão trabalhadas a partir da visão teórica de Georg Lukács, sobretudo, no primeiro volume da Estética I e em Marxismo e teoria da literatura. Pensamos haver uma forte intenção do poeta de concentrar a sua poética, ou seja, os métodos e motivos literários no seu livro intitulado Corpo. Esse livro, nesse sentido, é a sua última tentativa, ao lado de Farewell, de construir uma obra, cujos poemas são, ao mesmo tempo, coesos e aparentemente sem nexos, portanto, dialéticos, que abarquem toda a preocupação de fundir temas universais e particulares (filosófico-existenciais, sociais, amorosos) e o fazer literário (singularidade). Corpo é, propositadamente, a síntese da obra poética de Drummond de Andrade. Para desenvolver o nosso estudo acerca da poesia drummoniana, partiremos de dois pontos. Em primeiro lugar, consultaremos a sua fortuna crítica, tendo como centro da pesquisa bibliográfica o livro $O$ amor e outros aspectos em Drummond, do professor e poeta Linhares Filho; o texto "Inquietudes na poesia de Drummond", de Antonio Candido (Vários escritos); e a obra de crítica e interpretação de Affonso Romano de Sant'Anna, intitulada Drummond, o gauche no tempo. O segundo momento é a análise dos poemas de Corpo, fazendo um estudo intratextual com outras obras do poeta mineiro.
\end{abstract}

Palavras-chave: Drummond. Poesia. Estética. Crítica.

\begin{abstract}
Our goal is to analyze the poetic elements of Drummond as enriching of human life in its unique, particular and universal aspects. These categories will be worked from the theoretical vision of Georg Lukács, especially in the first volume of Aesthetics and in Marxism and literature theory. We think there is a strong intention of the poet to concentrate his poetics, that is, the methods and literary motifs in his book entitled Body. This book, in this sense, is his last attempt, alongside Farewell, to construct a work, in which poems are at the same time cohesive and seemingly without dialectical nexuses, which encompass the whole concern of merging universal themes and (philosophical-existential, social, loving) and literary doing (singularity). Body is purposely the synthesis of the poetic work of Carlos Drummond de Andrade. To develop our study of drummonian poetry, we will start from two points. In the first place, we will consult his critical fortune, having as a center of bibliographical research the book The Love and other aspects in Drummond, of the teacher and poet Linhares Filho; the text "Concerns in the poetry of Drummond", by Antonio Candido (various writings); and the work of criticism and interpretation of Affonso Romano de Sant'Anna, entitled Drummond, "The gauche in time". The second moment is an analysis of the poems of Body, making an intratextual study with other works of the poet from Minas Gerais.
\end{abstract}

Keywords: Drummond. Poetry. Aesthetics. Criticism.

\section{RESUMEN}

Nuestro objetivo es analizar los elementos poéticos de Drummond, como enriquecedores de la vida humana en sus aspectos singulares, particulares y universales. Estas categorías serán trabajadas a partir de la visión teórica de Georg Lukács, sobre todo, en el primer volumen de la Estética I y en el Marxismo y la teoría de la literatura. Pensamos haber una fuerte intención 
del poeta de concentrar su poética, es decir, los métodos y motivos literarios en su libro titulado Cuerpo. Este libro, en ese sentido, es su último intento, al lado de Farewell, de construir una obra, cuyos poemas son al mismo tiempo cohesivos y aparentemente sin nexos, por lo tanto, dialécticos, que abarquen toda la preocupación de fundir temas universales y (filosóficoexistenciales, sociales, amorosos) y el hacer literario (singularidad). El Cuerpo es, a propósito, la síntesis de la obra poética de Carlos Drummond de Andrade. Para desarrollar nuestro estudio sobre la poesía drummoniana, partiremos de dos puntos. En primer lugar, consultaremos su fortuna crítica, teniendo como centro de la investigación bibliográfica el libro El amor y otros aspectos en Drummond, del profesor y poeta Linhares Filho; el texto "Inquietudes en la poesía de Drummond", de Antonio Candido (Varios escritos); y la obra de crítica e interpretación de Affonso Romano de Sant'Anna, titulada Drummond, el gauche en el tiempo. El segundo momento es análisis de los poemas de Cuerpo, haciendo un estudio intratextual con otras obras del poeta minero.

Palabras clave: Drummond. Poesía. La estética. Crítica.

\section{Considerações iniciais}

Este texto será composto de duas etapas. Na primeira, que leva o nome de "O Universo Poético de Drummond", pretendemos fazer o levantamento crítico a respeito dos principais temas da obra poética (todo/geral) do escritor itabirano, a partir da sua fortuna crítica, para, em seguida, relacionarmos com o Corpo (particular). Entrarão nesse conjunto mais amplo os seguintes livros: Seminário do mundo (1940), A rosa do povo (1945), Claro enigma (1951), Lição de coisas (1962), Boitempo (1968), As impurezas do branco (1973), A paixão medida (1980) e Farewell (1996), além de uma antologia de alguns textos das principais obras do autor.

O segundo momento, intitulado "A Poética de Corpo" é mais pretensioso. Nele, tentaremos atingir o seguinte objetivo principal: analisar os elementos poéticos de Drummond, compreendendo-os como enriquecedores da vida humana nos seus aspectos singulares, particulares e universais.

Organizando dessa forma o discurso críticoanalítico acerca da poesia drummoniana, acreditamos deixar a intenção sobre o nosso ponto de vista, que é de desencadear uma discussão literária a partir dos âmbitos universal e particular suscitados pelo poeta e interpretar segundo a perspectiva teórica de Georg Lukács.

\section{O Universo Poético de Drummond}

Tratar do universo poético de Drummond é um empreendimento ambicioso, tendo em vista a natureza da análise que se desenvolverá neste trabalho. Uma vez que se trata de um artigo, abordaremos apenas alguns pontos da vasta poesia drummoniana, que tem um percurso de mais de cinquenta anos, haja vista seu primeiro livro, Alguma poesia, ter sido publicado em 1930, e o último cujo título é Farewell, em 1996, postumamente. São mais de vinte e cinco volumes em verso. Este capítulo, nesse sentido, tem a pretensão de apontar algumas características do emaranhado universo estético e temático das principais obras em poesia do escritor mineiro, tendo como ponto de partida a sua fortuna crítica. Isso é necessário a fim de compreendermos melhor, no próximo capítulo, Corpo (1986) como uma provável síntese desse universo poético.

Segundo Linhares Filho (2002), a poesia de Carlos Drummond de Andrade passa por quatro fases. A primeira, que compreende Alguma poesia e Brejo das almas (1934), é "predominantemente individualista" (LINHARES FILHO, 2002, p. 19). Isso significa dizer, sem dúvida, que a poesia, naquele momento, estava impregnada do subjetivismo do eu lírico, cuja visão de mundo (singularidade) limita-se ao particular das emoções interiores do sujeito.

Na segunda fase, que se inicia a partir de Sentimento do mundo (1940) até Novos poemas (1947), passando por José (1942) e Rosa do povo (1945), nota-se uma poesia muito mais preocupada com as questões sociais. Mas não só isso. Atingindo certa maturidade estética, o poeta conseguiu fundir, no espaço da poesia, um estilo próprio a temáticas universais, distanciando-se dos preceitos estético-ideológicos do Modernismo de 1922. Por isso, essas temáticas dizem respeito não mais ao individualismo da fase anterior, mas sim ao destino do homem em face do mundo. A vida, a morte, enfim, a existência da humanidade passa a ser questionada, sem ilusão, sem otimismo ingênuo. $\mathrm{O}$ mundo pelo qual apreende o cotidiano e transforma-o em símbolo, ultrapassa poeticamente os dois primeiros livros. Há, nessa etapa, um fazer poético mais demorado e preocupado com o material - a linguagem verbal - para a construção da poesia.

Entretanto, é na terceira fase de sua obra poética que Carlos Drummond de Andrade instaura, no espaço de sua 
escritura, a crítica do seu fazer literário, de modo mais consciente e sistemático. Assim afirma Linhares Filho:

De Claro enigma - 1951 a Lição de coisas - 1962 (publicando-se intermediariamente Fazendeiro do ar - 1953 e A vida passada a limpo - 1958), ocorre a fase em que o poeta passa a valorizar mais a forma, a linguagem, a palavra em si que o conteúdo. Nasce aqui a preocupação do autor com a metalinguagem, enfim, com os fenômenos do poético (LINHARES FILHO, 2002, p. 24-25).

Nesse momento, percebe-se que a poesia é voltada para si mesma, em busca de uma forma sempre mais apurada para fundir, no nível simbólico, a representação (poesia) e a realidade. A metalinguagem, que não é preocupação exclusiva de Drummond, corresponde à própria impossibilidade de construir a poesia ideal para resolver os problemas fundamentais e essenciais, por isso, universais, da humanidade como um todo. Dessa forma, a procura incessante do poeta no fazer poético traduz a própria angústia do homem em resolver os problemas que o afligem, sejam eles de ordem social, filosófica ou psicológica.

O último momento da poesia drummoniana, ainda de acordo com Linhares Filho, está impregnado do memorialismo do poeta mineiro: "Salientamos, nessa quarta fase, a mineiridade, o sentimento da família e da terra" (LINHARES FILHO, 2002, p. 26). Não quer dizer que com isso não haja nas fases anteriores da poesia de Drummond o aparecimento desses elementos como temática; claro que há. Só que nessa última etapa de sua obra, a partir de Boitempo (1968), o poeta itabirano retoma-os com mais frequência e relevância. Da mesma forma que Boitempo, os livros Menino antigo (1973) e Esquecer para lembrar (1979) giram em torno da infância e adolescência dentro do espaço-tempo da memória do poeta.

Há, pela complexidade de temas e estilos drummonianos, outras análises a respeito do universo poético do escritor em apreço. Affonso Romano de Sant'Anna (1972) desenvolve sua pesquisa literária a partir da categoria gauche, que significa uma postura peculiar "sem jeito", "ex-cêntrica" - do indivíduo diante de si e do mundo. A dinâmica responsável pela trajetória poética de Drummond, nesse sentido, é a fusão no plano simbólico do eu poético com o poeta, a partir do percurso que esse faz em relação ao tempo e ao espaço reais da vida. Essa trajetória, de acordo com a abordagem críticoliterária de Affonso Romano de Sant'Anna (1972, p. 17), divide-se em "três atos do drama existencial do gauche", e resume-se em "três momentos inseparáveis: Eu maior que o Mundo / Eu menor que o Mundo / Eu igual ao Mundo".
É interessante observar que a partir dessa relação "Eu" e "Mundo", a poesia de Drummond também pode ser explicada em etapas interdependentes. Assim, em Alguma poesia e Brejo das almas, encontra-se a fala egocêntrica de quem ainda não se socializou. Tendo como parâmetro o universo interior e psicológico de um indivíduo, e o desvão particular da memória, o gauche poético ainda não é capaz de compreender, do ponto de vista existencial, a humanidade e sua angústia. Daí o tempo e o espaço serem esteticamente retratados parcial e insuficientemente, uma vez que as emoções individuais do eu lírico predominam em relação ao mundo.

A partir de Sentimento do mundo, em que já existe uma voz mais experiente, cuja visão da realidade que envolve a todos se elastece, nota-se um aprofundamento entre a angústia do Ser e as querelas do mundo. As transformações nesse momento da poética drummoniana não são apenas temáticas, pois se percebe também um trabalho mais apurado da linguagem. Uma frase, simplesmente irônica de antes, substitui-se por um humor refinado, transfigurado em um estilo mais seguro.

O tempo e o espaço, nessa fase, deixam de ser retalhados e "atingem o multifoliado e o universal, que se configurariam ainda melhor em Rosa do povo" (SANT'ANNA, 1972, p. 89). Aqui o gauche compreende que o destino do homem no mundo é maior do que o seu sofrimento pessoal e a sua "ex-centricidade" individual. Portanto, no plano artístico, constrói os fundamentos de sua poética, que é a relação enigmática do Ser e do mundo, do particular e do universal, que consiste numa posição ontológico-existencial e dialética de pensar e questionar a realidade.

A apropriação do tempo como categoria poética tem, enfim, Sentimento do mundo como divisor: presente, passado e futuro, a fim de compreender melhor a plenitude da vida. Entretanto, isso ainda não é suficiente, uma vez que o poeta-gauche se depara com a morte, aproximandose cada vez mais "a cavalo de galope" (ANDRADE, 1994, p. 133). Dessa forma, ao esgotamento gradual da vida corresponde à problemática espácio-temporal, o que leva Affonso Romano de Sant'Anna a afirmar o seguinte:

A conquista do tempo, efetuada abertamente a partir de Sentimento do mundo, não era um ato de aquisição gratuita, senão uma surda, programada e desesperada luta contra a morte crescente. Neste sentido é que a batalha contra a corrosão se afirma por seus contrários, ao efetivar o poeta a anexação de seu passado, do passado alheio e do passado histórico à sua vida e ao se projetar no futuro (SANT'ANNA, 1972, p. 146).

Como uma tentativa de amenizar o destino da morte, o poeta, desde Claro enigma até Boitempo, sendo esse o último livro analisado por Romano de Sant'Anna, começa 
a trabalhar com mais intensidade a "intemporalidade da memória” (SANT'ANNA, 1972, p. 150) em seus versos. A poesia, por conseguinte, passa, por meio da força da palavra poética, a resgatar o tempo passado, mas também o tempo eterno da memória, podendo ser facilmente percebido na Arte em geral, principalmente na literatura. Alternando ininterruptamente entre os espetáculos da linguagem erudita, sofisticada e da linguagem comum do cotidiano, Carlos Drummond de Andrade, portanto, traduz a visão indireta - enigmática - que tem do homem, do mundo, da História, da sociedade e de si mesmo. Para tanto, o poeta se utiliza frequentemente de comparação e metáfora, além de outros tropos.

A abordagem teórico-crítica de Antonio Candido é outra importante análise que nos ajuda a entender com mais clareza a complexidade do universo da poesia de Drummond. Para Antonio Candido, é na maneira de trabalhar a palavra em si que consiste a dinâmica da poesia drummoniana. Nas duas primeiras obras, há apenas o registro dos fatos apreendidos individualmente pelo eu em relação ao mundo como assunto de poesia. Não obstante esses fatos sejam trabalhados a partir de uma técnica modernista, ou seja, anticonvencional, o poeta se limita a escrever versos sem a preocupação demorada com o fazer literário.

Somente a partir de 1935 que se percebe uma escritura crítica, uma vez que se interroga constantemente a ligação entre a produção poética, o sujeito social e o mundo. Dessa maneira, o que importa não é somente o que se diz, mas sobretudo de que modo se faz. Para dizer com as próprias palavras de Antonio Candido:

Entre 1935 e 1959, (...) a poesia parece desfazer-se como registro para tornar-se um processo, justificado na medida em que institui um objeto novo, elaborado à custa da desfiguração, ou mesmo destruição ritual do ser e do mundo, para refazê-los no plano estético (CANDIDO, 2004, p. 95).

Instaura-se, por conseguinte, no espaço da escritura poética de Drummond, a crise entre representação (arte) e a realidade (o ser e mundo). Daí ser, segundo os preceitos de Antonio Candido: "O bloco central da obra de Drummond, pois, regido por inquietudes poéticas que proveem umas das outras, cruzam-se e parecendo derivar de um egoísmo profundo, tem como consequência uma espécie de exposição mitológica da personalidade." (CANDIDO, 2004, p. 96, grifos do autor)

Nessa referida fase em questão, há uma espécie de impasse mal resolvido a respeito da identificação do Ser, mola mestra que intensifica a "inquietude", fazendo sempre o poeta oscilar entre o eu, o mundo e a arte. A procura constante do equilíbrio entre esses três elementos leva o poeta a debruçar-se desconfiado sobre a maneira de elaborar a poesia. Isso explica, talvez, os incontáveis metapoemas que existem ao longo da sua produção literária.

Além da identificação do ser, concorrem para a inquietude literária de Drummond a relação com o outro, o amor, a família, a sociedade e a morte, mas todos sob o universo individual do $\mathrm{Eu}$, o que lhe gera um forte "sentimento de culpa, indo ao limite da negação do ser, expressa pelo tema da auto-mutilação" (CANDIDO, 2004, p. 96). Entretanto, a poesia emerge no meio de tudo isso como metáfora da revolução ao mesmo tempo social e individual, aprofundando-se a partir de $A$ rosa do povo, fase estritamente social, de acordo com Antonio Candido.

Aos posicionamentos críticos apresentados até agora, acrescentam-se outras características, preocupações e tendências temático-estilísticas que condicionam e definem, em conjunto, o complexo universo poético de Carlos Drummond de Andrade. Compreendê-lo é significativo para analisarmos com segurança o objeto principal deste estudo, que é Corpo como síntese (particular) da poética (universal) drummoniana. Entretanto, não pretendemos nos demorar mais em considerações gerais, pois o que já ficou dito é o suficiente a respeito do assunto. Passemos, pois, para o cerne da nossa análise.

\section{A Poética de Corpo}

Vimos, no capítulo anterior, a história da poesia de Carlos Drummond de Andrade, que é a história de uma longa construção imagético-simbólica, desde a apreensão simples dos materiais, expondo-os ironicamente em sua elementaridade, até a tensão provocada pela maturidade no trato das questões literárias. Esta etapa que, agora se desenvolve, traz a proposta de analisar o texto do livro Corpo, publicado em 1986, sendo uma das últimas obras em poesia escrita por Drummond.

Sabe-se desde Aristóteles, que a Arte diz respeito a verdades universais, enquanto a história trata de fatos particulares (ARISTÓTELES, 1986, p.25). Nesse sentido, é notório que a universalidade em qualquer trabalho artístico é uma realidade, uma vez que encerra valores humanos por excelência. Entretanto, há obras que se preocupam mais com esse fato do que outras, a ponto de discuti-lo demoradamente no seu modo de construir a arte. Esse é o caso, especialmente, de Corpo.

Na trajetória da poesia de Drummond, já comentada, observamos o poeta indo ao encontro da sua expressão, do estilo próprio. Essa consciência artística é o que Mário de Andrade chama de "atitude estética diante da arte, diante da vida" (ANDRADE, 1975, p.33), como uma forma de eticamente viver sua "limitação" estética e poética. Por volta de 1940 a 1970, a poesia de Drummond, como 
vimos, aprofunda-se nessas questões. Categorias teóricocríticas como gauche, torção e inquietudes tornam mais tensa a tessitura dos versos sem, contudo, resolver o problema que aflige o poeta a respeito do eu, do mundo e da arte. A "pedra no meio do caminho" torna-se, portanto, um "claro enigma".

Corpo, a nosso ver, retoma toda a problemática da obra drummoniana, não como mera repetição, mas como outra tentativa do poeta de resolver as questões literárias e suas angústias diante da vida, do amor, da morte e de si mesmo. Por isso, as imagens, os temas e as querelas encontrados em Corpo são uma espécie de reunião particular de todo o universo poético de Drummond. Entretanto, desta vez, podemos entrever uma resposta, embora muito sutil, para os enigmas e as inquietudes existenciais e literários do escritor, imbuída no próprio título do livro. Analisemos de perto o poema "A metafísica do corpo", a fim de comprovar a nossa argumentação:

A metafísica do corpo se entremostra
Nas imagens. A alma do corpo
Modula em cada fragmento sua música
De esferas e de essências
Além da simples carne e simples unhas.
Em cada silêncio do corpo identifica-se
A linha do sentido universal
Que à forma breve e transitiva imprime
A solene marca dos deuses
E do sonho (ANDRADE, 1986, p. 11-12).

Juntamente com os poemas "As contradições do corpo" e "O minuto depois", o texto acima retrata o corpo e a alma, a partir dos quais se busca alcançar a essência e o universal, embora partindo de uma experiência particular do eu lírico. Há, então, um jogo dialético entre a matéria (concreto) e a essência, entre a objetividade da experiência e a subjetividade do ser. É na fusão desses dois elementos (carne e espírito) que surge o Ser. Ao falar do corpo, o artista também deixa entremostrar a "Ideia", a essência, a metafísica do corpo nas "imagens" poéticas. Somente a Arte, como um complexo de atividade humana, é capaz de resgatar a essência (a Ideia) a partir do particular. Drummond constrói, a nosso ver, a sua própria teoria da Mímese.

Sabemos que o conceito de mímese (como representação poética) vem desde Platão, que depreciava o processo mimético das obras de arte, por deixá-las distanciadas no terceiro nível em relação à essência das coisas. (PLATÃO, 1997) A partir do Classicismo da Renascença, os poetas e teóricos resgataram o conceito de mímese aristotélica como valorização da Arte. Essa, segundo Aristóteles, fundamenta-se a partir do instinto para a imitação e para o prazer, daí o homem se interessar naturalmente para (re)criar a vida, o mundo e a si próprio, por meio de artifícios artísticos.

Desde então, a mimese se tornou uma das categorias mais importantes da Arte, passando a ser o nervo da teoria literária, uma vez que trata da relação entre o fazer artístico e a sua representação. Essa relação torna-se ainda mais complexa no texto moderno, precisamente no de Carlos Drummond, que é o objeto específico da nossa análise.

Retomada desde o Renascimento, a mimese aparece nos estudos contemporâneos de literatura como elemento imprescindível para entender a natureza e a autenticidade do fazer poético, seja para confirmá-la, seja para questionála. Dessa forma, ao representar "nas imagens" o corpo, a essência também se entremostra, uma vez que a poesia tem o poder de trazer para a superfície a Ideia, mesmo sendo essa metafísica. Embora falando do particular, a arte, pois, transcendendo-o, torna-o universal.

Sant'Anna (1972, p.28) disse que Drummond "constrói um tipo literário - gauche - que, partindo de componentes específicos de sua personalidade, atinge, no entanto, o plano universal. E como tal ele se converte num personagem em quem se identifica o leitor”. Já percebemos a preocupação do poeta em atingir "o plano universal" a partir de "componentes específicos de sua personalidade" em obras anteriores. Entretanto, em Corpo talvez não haja mais sequer o personagem gauche; o que existe é o corpo, cantado em terceira pessoa, tornando-se paradoxalmente universal. Ainda na primeira estrofe do poema "A metafísica do corpo", as palavras "metafísica", "alma", "esferas" e "essências" contrastamse e completam-se mútua e dialeticamente com os termos "corpo", "fragmento", "carne" e "unhas": estes sugerindo a ideia de particular, aquelas apontando para o universal.

$\mathrm{Na}$ segunda estrofe, os versos "Em cada silêncio do corpo identifica-se / a linha do sentido universal" são a chave do poema e do livro como um todo, uma vez que os nossos mitos, metonicamente representados na palavra "deuses", e as nossas utopias ("sonho"), motivos primordiais para a vida e a arte, são encontrados em nós mesmos. O poeta deixa clara a sua postura existencialista acerca do homem no mundo. Essa postura de encarar a vida identifica-se ainda mais nas três últimas estrofes do poema em análise, em que o "pensamento da unidade inicial do mundo" é "mais que natureza", porque se encontra no "ser telúrico, espontâneo", cujo "corpo" passando pelos elementos "terra, seiva e amor" transforma-se em ser (ente), "na transparência do invólucro perfeito".

Linhares Filho, ao estudar especificamente o livro Corpo, abre-nos caminhos preciosos para o entendimento do texto drummoniano, quando afirma: "No livro Corpo (1986) só aparentemente se canta o corpo, pois o que mais nele se canta é o espírito, tido como essência. Há no 
livro uma insistente meditação metafísica sobre o corpo" (LINHARES FILHO, 2002, p. 65). Corpo, nesse sentido, figura como uma grande obra, pois, remetendo-se ora a si mesma ora ao conjunto poético do escritor mineiro como um trabalho intratextual, apresenta uma coesão, uma importante e poderosa unidade orgânica. Vejamos outro poema:

\section{Este pintor}

Sabe o corpo feminino e seus prováveis

De linha e de volume reinventados.

Sabe a melodia do corpo em variações entrecruzadas.

Lê o código do corpo, de A ao infinito

Dos signos e das curvas que dão vontade de morrer

De santo orgasmo e de beleza

(ANDRADE, 1986, p. 19).

O texto supracitado é o poema "O pintor de mulher". Nele há uma apreciação do poeta em relação à arte de pintar, ou representar através da pintura, o "corpo feminino". A partir da reflexão sobre a representação (mímese) do corpo, o poeta, tal qual um estudioso da obra de arte, é impulsionado a debruçar-se também sobre os aspectos materiais, ou seja, a forma como o plano das significações e dos sentidos se organiza para a composição estética do corpo (e por extensão do mundo). Também se debruça sobre os elementos estéticos, que são associados à noção de Belo, cuja configuração é diferente em cada período da história da Arte.

Ao afirmar, nos três primeiros versos, as várias possibilidades de representação artística ("linha e volume reinventados"), o poeta nos chama a atenção sobre a habilidade que o pintor tem com os materiais. Ademais, subentende-se que, além da técnica que é a habilidade do artista com as exigências do material para que a obra de arte se faça, a finalidade mesma da arte para o poeta não exclui os caracteres e exigências humanos, individuais e sociais, do fazer poético. Esse modo de ver a arte, a partir da pintura do "corpo feminino", aproxima-se da visão de Mário de Andrade, quando diz: "a terceira e última região da técnica é a solução pessoal do artista no fazer a obra de arte. Esta faz parte do 'talento' de cada um, embora não seja todo ele" (ANDRADE, 1975, p. 15).

Essa "solução pessoal" trabalhada por Drummond, para resolver os conflitos temático-estruturais de sua poesia, encontra-se na relação entre o particular e o universal cuja presença podemos perceber em qualquer manifestação artística, por tratar-se da natureza da Arte. Assim, Drummond, consciente de seu papel como artista na sociedade, pouco a pouco a desenvolve e aperfeiçoa durante toda a sua obra para, em seguida, concentrar essa problemática, que diz respeito à arte em geral, em Corpo. Esse ambicioso empreendimento inicia-se a partir da própria experiência do poeta colocada ainda no centro das questões nos primeiros livros. Aprofundando nas obras subsequentes o particular do seu cotidiano, entram em crise tanto os questionamentos universais (como o seu estranho relacionamento com os outros e a sociedade, a condição humana, a vida, o amor, a existência e a morte) como também as querelas em torno do fazer poético. Falando de modo tão consistente e insistente sobre a natureza humana e artística (singular), o poeta consegue atingir o âmbito universal, porque o leitor em contato com os versos drummonianos sente uma áurea envolver todo o corpo, passando a reconhecer-se na poesia e refletir sobre a existência e o destino do homem no universo.

É interessante observar, ainda, que a "destruição física" do corpo em relação ao tempo da existência, percebida ao longo da obra, é resolvida nos primeiros poemas que iniciam Corpo, como em "As contradições do corpo":

Quero romper com o meu corpo, Quero enfrentá-lo, acusá-lo, Por abolir minha essência, Mas ele sequer me escuta E vai pelo rumo oposto.

Já premido por seu pulso De inquebrantável rigor, Não sou mais quem dantes era: Com volúpia dirigida, Saio a bailar com meu corpo (ANDRADE, 1986, p.7-9).

Nos versos supracitados, não há mais somente a interrelação entre o físico e os objetos ao redor, mas sim com o próprio interior do ser, a essência. Segundo Sant'Anna, a temática do corpo aparece desde as primeiras obras em verso de Drummond, como centro gerador de outros poemas (SANT'ANNA, 1975). Inicialmente, o que havia era sensualidade dos versos reveladores de um tempo no qual o poeta via um corpo capaz de compatibilizar-se com os prazeres carnais e mundanos. Entretanto, a partir de A rosa do povo, o tom irônico e sensual do verso é substituído por um amargo e angustiante. Nesse momento, o poeta experimenta a derrota do corpo em relação ao tempo presente, de uma forma niilista.

Em Corpo, essa destruição é malograda ("saio a bailar com meu corpo"), pois o poeta adquire a consciência da impossibilidade de afastar-se do corpo, do material (particular) para tornar-se pura essência (universal). A existência no universo precisa, então, do corpo. Preso a este é que o Ser toma forma e concretizase a partir dos sentidos, embora seja um prisioneiro dele. Aqui cabe uma postura muito refinada do existencialismo ontológico de Georg Lukács, do ponto de vista da criação 
artística. Entretanto, não se vê mais a transferência do corpo para os objetos circundantes, através do processo de antropomorfização.

A intemporalidade, a existência dos seres e das coisas, enfim, o nascimento do universo encontra-se em nós, no interior do Ser. Assim, o poema "O outro", cujos versos iniciam com a pergunta que desarma o leitor: "Como decifrar pictogramas de há dez mil anos / se nem sei decifrar / minha escrita interior?" (ANDRADE, 1986, p. 29)

Podemos traduzir facilmente "escrita interior" como o delineamento da alma, tida como essência, ou seja, a transição metafórica do Ser, a partir do qual, somente do qual (a pergunta da estrofe nos leva forçosamente a essa única resposta) originam-se as coisas do mundo, ou pelo menos o conhecimento delas e por conseguinte a sua existência, pois algo só existe para nós se a conhecemos. $\mathrm{O}$ universo introspectivo, que é o confronto infinito do eu com o outro, é, portanto, o causador, a origem, do universo exterior. Este se modifica, como "signos dúbios a cada segundo de observação". Isso nos faz lembrar uma visão impressionista do mundo.

Dialogando com "O outro", o poema "A hora do cansaço" (ANDRADE, 1986, p. 39-40) fala-nos sobre a relatividade do eterno que reside nas coisas e pessoas, pois elas são eternas ou infinitas (universais) dependendo da vontade que há dentro de nós (particular). Esse modo de construir a poesia não surge originalmente em Corpo. O poema "A palavra e a terra", na primeira parte do livro $A$ paixão medida (1980), chamada "Origem", inicia-se com os seguintes versos: "o corpo na pedra / a pedra na vida / a vida na forma” (ANDRADE, 1994, p. 11). Há nesses versos um encadeamento, no qual o "corpo" é a origem vital de tudo, fecundado na matéria bruta e primitiva da "pedra". Esta, no segundo verso, a nosso ver, assume outra conotação, pois, relacionando-se com a "pedra" do poema "No meio do caminho" (Alguma poesia), ela sugere os obstáculos e as dificuldades de toda ordem que encontramos na vida. No terceiro verso, a "vida", embora sendo efêmera, consegue transcender-se na "forma" que simboliza a Arte.

Extremamente significativa é a construção dos poemas "Eu, etiqueta" (ANDRADE, 1986, p. 85-87) e "Favelário nacional" (ANDRADE, 1986, p. 109-124) para entendermos a conotação que assumem o particular e o universal na poesia de Carlos Drummond de Andrade. Esses dois textos retomam a temática social, especificamente brasileira, das obras poéticas da segunda fase, que como já sabemos inicia-se com Sentimento do mundo (1940).

"Eu, etiqueta" é uma crítica à sociedade de consumo, entretanto, não se resume apenas a uma crônica satírica. O modo como é construído o poema coloca em xeque a luta entre o indivíduo e a sociedade: esta corresponde particularmente à capitalista subdesenvolvida; aquele, a qualquer homem diante do desespero de perder sua identidade frente ao fetichismo da mercadoria. As raízes do ser individual entram em conflito com a práxis do ser social, na superficialidade do consumismo global; o que resulta um homem alienado na concepção marxiana. Nesse sentido, a problemática do eu lírico (a perda da identidade, a anulação do ser social, a falta de gosto e a incapacidade de escolher, o esgotamento das indissiocrasias pessoais), corrompido pela fraqueza do "corpo que desiste", tornase muito mais universal do que a particular sociedade de consumo, uma vez que se trata de sentimentos conflitantes de todo o ser humano em face de um determinado problema social. Portanto, a partir de uma particular situação na sociedade, instauram-se querelas universais no interior do sujeito, cuja subjetividade relaciona-se constantemente com a objetividade da práxis social.

Em "Favelário nacional", não há a mera descrição física da favela, pois esta se universaliza na medida em que é tratada como um organismo vivo, um Ser, um corpo pensante na práxis social do cotidiano coletivo da população que povoa um espaço em comum, não sem conflitos e tensões. A primeira parte do poema, cujo título é "Prosopopeia", mostra de imediato a intenção do poeta em considerara "favela" como um ser animado, antropoformizando-a. ademais, dirige-se a ela através do vocativo, articulando o discurso entre a primeira pessoa - o eu lírico que canta - e a segunda pessoa - a favela para quem o canto se dirige. Vale a pena transcrevermos um trecho desse curioso poema: "Dentro de nós é que a favela cresce / e, seja discurso, decreto, poema / que contra ela se levante, / não pára de crescer" (ANDRADE, 1986, p. 121).

Consideramos essa passagem o cerne do poema "Favelário nacional" como um todo. Nela, encontramos também a tensa dualidade entre o particular e o universal. A origem da favela está "dentro de nós", o que explica a sua universalidade. A Palavra, subentendida nos termos "discurso", "decreto" e "poesia", torna-se impossibilitada diante da realidade histórica e social, uma vez que, assim como o surgimento, a destruição das favelas e de todos os absurdos que lá existem, apontados ao longo do poema, está "dentro de nós", ou seja, é uma problemática da práxis humana e não um fenômeno da natureza. Nesse sentido, podemos facilmente relacionar a postura que o poeta assume sobre a impossibilidade da poesia como instrumento de revolução com o trecho do texto de Otávio Paz, que indaga o seguinte:

[...] a interrogação sobre as possibilidades de encarnação da poesia não é uma pergunta sobre o poema e sim sobre a história: será uma quimera 
pensar em uma sociedade que reconcilie o poema e o ato, que seja palavra viva e palavra vivida, criação da comunidade e comunidade criadora? (PAZ, 1976, p.95)

Não é difícil aproximar o poema de Carlos Drummond de Andrade ao discurso teórico de Otávio Paz. Tanto em um como em outro, cada um a seu modo, vemos claramente a preocupação de associar poesia e realidade, sendo uma resultante da outra, existindo mútua e interdependentemente.

O poema "Por que?" é a síntese básica, ao mesmo tempo, da trajetória do homem na terra e da temática da poesia drummoniana: "Por que nascemos para amar, se vamos morrer? / Por que morrer, se amamos? / Por que falta sentido / ao sentido de viver, amam, morrer?" (ANDRADE, 1986, p. 47) As indagações sobre os verbos de ação "nascer", "viver", "amar" e "morrer" constituem o questionamento do sentido da existência humana. Esta, para o poeta parece ser desacreditada e desnecessária, uma vez que não há coerência no percurso existencial do homem na Terra. Enfim, as perguntas, extremamente filosóficas, que formam o poema em apreço, são necessárias ao poeta a fim de reconhecer o seu universo interior.

A metapoesia também aparece em Corpo (ANDRADE, 1986), mais precisamente nos poemas "Lição" (1986, p. 79), "Passatempo" (1986, p. 89) e "Lembrete" (1986, p.95), retomando a reflexão sobre o sentido da escrita como obra de arte. Estão presentes neles as preocupações básicas da obra de Drummond, que são a compreensão de si mesmo, desvendamento da vida e a tentativa de distinção entre essência e aparência, a partir do próprio processo de escritura poética. Esse, em "Lição", é totalmente dispensável diante da verdadeira Poesia que traduz o verso "ode cristalina".

Em "Passatempo", em uma espécie de brincadeira palavra puxa palavra, encontramos mais uma vez a oposição significativa entre o particular e o universal. O "verso", que é uma construção individual do poeta, configura como o particular, mas infinitas possibilidades que a língua nos oferece. Ademais, a ambiguidade instaurada, propositadamente, nos versos conduz-nos a uma dupla interpretação em relação a quem o poeta verdadeiramente se refere: se é ao "eu" (particular) ou a qualquer um - o Poeta - (universal). Termina a poesia de uma única estrofe afirmando o esgotamento da composição poética ("o que lavra") diante daquilo que ele tem para exprimir. Portanto, o poeta "só encontra meia palavra”, ou seja, o inefável.

O poema de três versos "Lembrete" contextualizase com os dois já analisados acima, pois mantém o jogo dialético entre poesia versus a vida. Nele, observamos que o universo misterioso da vida dá lugar ao universo da poesia, porque é por meio da singularidade desta que se forma uma consciência de uma ordem individual para suprir o caos do mundo exterior.

Em "Canção de alinhavo" (ADNRADE, 1986, p.97-105), poema curioso pelas múltiplas imagens suscitadas, vemos um esboço do que fora não somente a vida do poeta, mas também da sua obra poética, construído de forma nebulosa e surrealista. O que nos interessa nele, no entanto, são somente as partes "V" e "X", pois também nos deixam entrever a relação entre o particular e o universal, como uma espécie de revelação para o enigma da poesia, que talvez pareça ser o mesmo enigma da vida. Para entendermos melhor a nossa argumentação, vejamos mais de perto alguns versos:
Condenado a escrever o mesmo poema
E ele não alcança perfil definitivo.
Talvez não exista. Perseguem-me quimeras.
O problema não é inventar. É ser inventado
Hora após hora e nunca ficar pronta
Nossa edição convincente

(ANDRADE, 1986, p. 100).

Consideramos o trecho acima a "chave de ouro" para o desvendamento do universo poético de Drummond. Nele, o poeta admite estar à procura de um poema que expresse adequadamente o sentimento individual em sua totalidade. Essa constatação no próprio corpo do texto ajuda-nos a compreender o significado do livro Corpo, como mais uma tentativa de recuperar a partir da poesia a transcendência do seu ser. Entretanto, a forma ("perfil definitivo") não é suficientemente capaz de suportar todo o peso das emoções, dos sentimentos, da experiência de vida, dos sonhos, dos amores, enfim, do universo interior do poeta.

Nos três últimos versos supracitados que servem de epígrafe ao livro, nós temos a confissão direta que significa a ligação interdependente entre a poesia e aquele que a constrói. Não é por acaso, então, que Drummond, durante toda a trajetória literária, transfere repetidamente os anseios e angústias pessoais para a sua poesia, a fim de descobrir-se e completar. Portanto, ao escrever Corpo, o poeta já havia atingido não só a maturidade artística, mas também a integridade humana, intensificando agora no seu próprio ser os motivos e os modos de criação artística, ou seja, a práxis do sujeito social é afetada pela subjetividade do poeta e vice-versa, numa relação dialética. Logo, partindo do particular da experiência de mundo, o poeta alcança âmbitos universais através da singularidade poética de seus versos.

Quanto à parte "X" do poema em análise, o poeta relaciona o universo de constelações com o destino do indivíduo, terminando com os seguintes versos: 
Será soberbo desatar-me de laços precários

Que em mim e a mim me prendem e turvam

A condição de coisa natural. Não serei mais eu,

Nenhum fervor ou mágoa me percorrendo. Plenitude

Sideral do inexistente indivíduo

Reconciliado com a matéria prima.

Alegria, sem este ou qualquer nome. Alegria

Que nem se sabe alegria, de tão perfeita.

Minha canção de alinhavo resolve-se entre cirros

(ANDRADE, 1986, p. 104-105).

No excerto transcrito acima, não é fácil interpretar o significado de seus versos. O certo é que se percebe o poeta desejoso de liberdade ("desatar-me") e de reconhecimento de suas origens ("condição de coisa natural"). Mas que "laços precários" são esses? São, talvez, as limitações, hipocrisias e disfarces sociais que nos forçam a ser artificiais. Nesse sentido, o ser social, mascarado, descarnado e indiferente, será substituído pelo ser cujo corpo e alma serão lavados da culpa ou remorso. Só assim, o poeta chegaria à "plenitude / sideral do inexistente indivíduo / reconciliado com a matéria prima". Nesse trecho, o universo encontrar-seia dentro do próprio indivíduo. Portanto, sem perder de vista o valor intrínseco da obra ("matéria prima"), que se confunde com o valor intrínseco do Homem, ambos responsáveis pela legitimidade e peculiaridade artísticas no sistema social, a poesia drummoniana é tomada de repleta humanidade.

Outro ponto relevante para compreendermos Corpo como síntese do universo poético de Carlos Drummond é analisar um pouco a temática do amor, que percorre uma trajetória importante na obra em versos do poeta mineiro. $\mathrm{O}$ incentivo para a nossa argumentação críticoliterária de que o amor drummoniano também cumpre uma relação de âmbitos particular e universal partiu da seguinte afirmação de Linhares Filho:

Não falaremos especificamente do amor como solidariedade humana, esse "sentimento do mundo" que abrange o âmbito social e o universal, e que está bem forte e legitimado artisticamente na obra de Drummond, sobretudo em A rosa do povo. Falaremos do amor como sentimento psicofísico, que marca a atração entre as pessoas de sexos diferentes, que também é universal, e que pode considerar-se imagem e fundamento do amor como solidariedade humana (LINHARES FILHO, 2002, p. 29).

Segundo a advertência do professor e escritor Linhares Filho, supracitada, a respeito da sua intenção de desenvolver um texto, existem dois tipos de amor na poesia de Drummond: o amor social e o amor individual. Ambos são universais, uma vez que estão embutidos no sentimento humano, e estão presentes em Corpo, embora o primeiro menos frequente do que o segundo. Nos poemas "O amor e seus contratos" (ANDRADE, 1986, p. 15-16), “As sem-razões do amor" (ADNRADE, 1986, p. 35-36), "A hora do cansaço" (ANDRADE, 1986, p. 39-40) e "O seu santo nome" (ANDRADE, 1986, p.43), encontramos a presença mais forte do amor individual, ao passo que em "Aparição" (ANDRADE, 1986, p. 37) e "Os Amores e os mísseis" (ANDRADE, 1986, p.91-93), o amor como solidariedade social prevalece. Tanto um como o outro, diga-se de passagem, caracterizam-se como uma visão realista do poeta a partir da experiência de mundo dele.

Podemos afirmar, então, que a temática amorosa de Drummond, desde suas obras anteriores, forma-se a partir de antíteses, em que se percebe o "dualismo construção-destruição, ganho-perda, instante-eternidade e se representa através de algumas imagens continuadas" (SANT'ANNA, 1972, p. 177), para exprimir-nos com as palavras de Afonso Romano Sant'Anna. Pensamos, pois, que o paradoxo existente no modo de cantar o amor recebe um desfecho significativo em Corpo, ressaltando a natureza universal imanente a esse sentimento, pois é ele o mais humano de todos. O poeta, pela sua magnífica sensibilidade, reconhece-o como tal, por isso o canta de todas as maneiras, incansavelmente. Dessa maneira, vamos encontrar no livro em análise tanto o amor metafísico, eterno e universal, como também o amor individual, carnal, entre amante e amada, sujeito e objeto de desejo. Colocados no mesmo nível de necessidade humana, ambos recebem o mesmo tratamento e importância para o reconhecimento do Ser.

A memória, associada à noção de tempo e espaço, é também significativa para a construção temático-estrutural de Corpo. A série de poemas "A chave" (ANDRADE, 1986, p. 63-65), "O céu livre da fazenda" (ANDRADE, 1986, p. 67-69), "Canção de Itabira” (ANDRADE, 1986, p. 71-72), "Mudança" (ANDRADE, 1986, p.73), “O ano passado" (ANDRADE, 1986, p.75-76), "O céu" (ANDRADE, 1986, p. 77), "Lição" (ANDRADE, 1986, p.79) e "Ouro Preto, livre do tempo" (ANDRADE, 1986, p. 81-84), fala, de uma forma ou outra, do tempo e do espaço, puxados do particular interior do poeta pela memória e retrabalhados pela singularidade da linguagem poética. Ao identificar-se com esse sentimento, no ato da leitura do poema, o leitor encontra a possibilidade de refletir sobre sua própria experiência enquanto ser social. Nesse sentido, a poesia de Drummond universaliza a particularidade do eu lírico.

No poema "A chave" (ANDRADE, 1986, p. 65), as expressões "porta principal", "imenso", "Outros" e "ato de criação" são expressões que podem também traduzir a ideia de universal, ao passo que os termos "revelando o que não sei de mim", “coisa criada", "voz”, "mudez", "terra”, 
"entranha" e "veias", lembram-nos sem o menor esforço a particularidade da figura do ser. A linguagem, nesse jogo dialético, tem um papel fundamental, uma vez que ela resgata o tempo, o espaço e as coisas e seres do passado, concretizando-os eternamente na poesia. Entretanto, a linguagem é somente um meio de exteriorizar aquilo que "corre nas veias": a lembrança de uma vida inteira. Portanto, "é dentro em nós que as coisas são", queimando vivas como "ferros em brasa", eis aí mais uma "chave" que desvenda, a nosso ver, o enigma drummoniana. As coisas do mundo só atingem o âmbito universal, porque a origem delas está no particular do Ser.

Enfim, a memória do tempo, em que guarda os perfis de cada um de nós (infância, juventude e velhice), e do espaço onde se escondem os nossos mitos, alcança, em Corpo, o ápice da maturidade, que percebemos nos seguintes versos do poema "Canção de Itabira": "Mesmo a essa altura do tempo, / um tempo que já se estira, / continua em mim ressoando / uma canção de Itabira" (ANDRADE, 1986, p. 71).

A oposição entre o localismo e o universalismo (SANT'ANNA, 19, p. 76) encontra em Corpo um ponto comum, pois o sentimento tanto da província como da metrópole brota-se no interior do corpo do poeta. Aprofundando, pouco a pouco, em cada livro de poesia escrito a temática da memória, o poeta luta contra a morte e a destruição física do corpo. Logo, recupera através da linguagem poética de a "Canção de Itabira". Com isso, somos obrigados a recorrer novamente às palavras tão certas de Sant'Anna, quando ele diz que a "temática do corpo transcende o narcisismo dos primeiros livros, chegando o indivíduo a operar, diante do tempo que inflige ao seu corpo, uma observação fenomenológica onde corpo-consciência são um conjunto indissolúvel" (SANT'ANNA, 19, p. 76). Corpo, retomando em síntese, porém com reflexão mais demorada, o conjunto indissolúvel do "corpo-consciência", é a posição, em plena madureza do poeta, que para falar do universal precisa antes conhecer bem os labirintos de seu espírito e corpo, partes integrantes do Ser.

Outros temas não menos relevantes que habitam as obras anteriores de Drummond também encontram lugar significativo no espaço poético de Corpo. São exemplos disso a morte, retratada ainda com certo humor, nos poemas "Mortos que andam" (ANDRADE, 1986, p. 49), "Como encarar a morte" (ANDRADE, 1986, p. 51-53) e "Inscrição tumular" (ANDRADE, 1986, p. 55); o duelo entre Deus e o homem, em "Deus e suas criaturas" (ANDRADE, 1986, p. 59) e "Hipótese" (ANDRADE, 1986, p. 61); a relação entre a longa experiência do poeta e seu fazer literário, em "Flor experiente" (ANDRADE, 1986, p. 33); e o erótico em "Dezembro" (ANDRADE, 1986, p. 17).
Há, por fim, outros poemas como "Maternidade" (ANDRADE, 1986, p.21), "Homem deitado" (ANDRADE, 1986, p. 23), "A ausência" (ANDRADE, 1986, p. 25), "História natural" (ANDRADE, 1986, p. 27) e "Duende" (ANDRADE, 1986, p. 25), com os quais não arriscamos fazer uma interpretação ligeira, colocando-os na mesma esteira dos demais, para justificar a dialética do particular e universal presente em Corpo, obra-síntese da poética drummoniana. Não obstante o curto tempo, inimigo de toda reflexão crítica, que temos para escrever, consideramos a argumentação literária desenvolvida aqui suficiente para validar a nossa análise.

Levando em conta que o texto poético constrói sua própria teoria, pois tem valor eminentemente intrínseco capaz de revelar múltiplas significações, estamos ciente de que o nosso discurso crítico empregado como metodologia de análise não é um único possível no emaranhado de sentidos que oferece a poesia de Carlos Drummond de Andrade. Diante da imensa carga de subjetividade que envolve os versos do poeta em apreço, cremos que a nossa investigação sobre os aspectos particular e universal configura-se, no meio de sua grandiosa fortuna crítica, como uma humilde voz para contribuir nos estudos literários de seu universo poético.

Corpo, nesse sentido, une as duas pontas de um mesmo barbante, quando coloca também em questão a dialética entre o eu (particular) e o mundo (universal). O poema "Balanço", transcrito em seguida, serve-nos como exemplificação analítica a respeito do assunto: "A pobreza do eu / a opulência do mundo // A opulência do mundo / a pobreza do mundo // A pobreza de tudo / a opulência de tudo // A incerteza de tudo / na certeza de nada" (ANDRADE, 1986, p. 107).

O poeta, em uma espécie de brincadeira de balanço, sugerida pelo ritmo das estrofes com dois versos cada, revela a imbricação significativa que serve de referência para os motivos literários de sua grandiosa obra em versos. A sua poesia, assim, oscila entre dois temas centrais, a partir dos quais outros menores se entrelaçam: o eu e o mundo. Além desse movimento alternado em sentidos opostos, o termo "Balanço" ainda nos lembra a exposição pormenorizada (particular) do conjunto da obra (geral/totalidade). É claro que essa disposição de temas sugeridos na poesia de Drummond resulta, sobretudo, de um ato estético que transcende a realidade do mundo imediato, mas não a nega. Por ser, antes de tudo, arte, a obra poética de Drummond "apresenta-se como um universo particular, que se distingue de todo outro universo pelo que contém e pelo que exclui" (JOSEF, 1980, p. 86), ou seja, pela sua singularidade artística.

Ademais, o paradoxo instaurado a partir dos termos "pobreza/opulência", "eu/mundo", "incerteza/certeza" e "tudo/nada", no corpo do texto, são possíveis de serem 
associados à própria dialética da vida. $\mathrm{O}$ universo desta, portanto, encontra correlato no universo da arte, não obstante a diferença de natureza de ambas: esta é, segundo Aristóteles, a representação simbólica daquela, ou seja, não é uma cópia da vida, mas como esta deveria ser. Enfim, explorando demoradamente a temática particular versus universal em Corpo, o poeta mineiro consegue manifestar-se em toda a sua plenitude, tanto do ponto de vista da forma como dos assuntos.

\section{Considerações finais}

Conhecendo mais de perto a prática literária de Carlos Drummond de Andrade, desenvolvemos a respeito de sua poesia uma análise crítica que se propõe a estudála sob dois aspectos: o particular e o universal. Somos conscientes de que o ponto de vista tomado aqui é apenas um entre muitos possíveis, uma vez que a literatura, como objeto artístico, possibilita múltiplas interpretações. A nossa, que é analítico-reflexiva, desenvolveu-se a partir de um estudo criterioso do texto poético do autor, além da pesquisa bibliográfica da sua fortuna crítica, seguindo exatamente todos os passos de um artigo acadêmico.

O trabalho de crítica literária desenvolvido por nós dividiu-se em dois capítulos que são complementares. O primeiro foi necessário como uma espécie de visão geral do conjunto da obra em versos do autor. O segundo, cerne do estudo, pesquisou a ocorrência frequente do universal e do particular, por meio da investigação textual, valorizando a sua existência para a construção de temas e imagens.

Seguindo um estudo literário do texto como linha metodológica principal, constatamos, no decorrer da nossa análise, que há na estrutura poética de Corpo uma frequência significativa de elementos particulares e universais. São, a nosso ver, construídos e fundidos, propositadamente, como uma tentativa de resposta às "inquietudes" literárias e humanas, fundamento da Poética drummoniana, segundo Antonio Candido.

Ademais, as tensões do eu poético no conjunto da obra de Drummond e, particularmente, em Corpo, geram constantes contradições, uma vez que há o confronto entre ele e a vida. Dessa forma, podemos concluir que ao sentimento particular do mundo funde-se universo do ser social, entendido por nós como uma relação ontológica lukacsiana. Em Corpo, portanto, síntese (complexa) da obra poética de Drummond, percebemos que a poesia se torna mais universal, pois se aprofunda no particular do ser social (a existência, a essência e a condição humana).

Essa valorização do particular e do universal não é apenas de cunho crítico-interpretativo, mas também teórico, uma vez que eles pertencem à natureza da Arte, como bem teorizou Georg Lukàcs em seu fenomenal livro, intitulado Estética I. No "uni-verso" drummoniano, ou seja, no estilo individual (singularidade poética, maneira peculiar de ver, sentir, interpretar e expressar o mundo e a si mesmo, consequentemente, de escrever), instaurase o universal que são milhares de razões da dimensão humana (graus diversos de identificação e distanciamento em relação à humanidade).

Lançando um olhar atento para poética de Drummond, podemos depreender temas e imagens que se associam ao particular, tais como: o efêmero; os círculos menores de grupos sociais ou comunidades; o localismo da província; a intimidade física, psicológica e familiar; o estilo individual; a escolha de palavras e construções mentais; o indivíduo; a cultura brasileira; o conhecimento individual; a singularidade da forma poética; o limite; o corpo; o homem; o amor carnal; a visão subjetiva e pessoal do poeta; o provisório e o imediato; as emoções pessoais; a realidade do mundo visto por um homem, cuja experiência de mundo é única devida à sua subjetividade; o materialismo; o reconhecimento dos fatos da experiência pessoal; o sentimento do mundo; o espetáculo objetivo do mundo do ser social; os problemas colocados para o eu lírico; o cotidiano; a aparência das coisas; o circunstancial.

Ao passo que as seguintes palavras e expressões que servem de motivos literários para a poesia de Drummond sugerem a ideia de universal: ruptura; espírito; essência; enigma humano; vida X morte; metafísica; transcendência; alma; Ser; Amor; sentimentos e emoções universais; realidade da arte; idealismo; utopia; espetáculo espiritual do mundo; problemas universais; universo das palavras, do sonho, do amor, das ideias, da existência, do medo. Do mito, das tensões e conflitos, das perguntas e dúvidas, da poesia; a verdade; o eterno; o lírico; o universo humano; o conhecimento; o trabalho social.

\section{Referências}

ANDRADE, Carlos Drummond de. Corpo. 9. ed. Rio de Janeiro: Record, 1986.

ANDRADE, Carlos Drummond de. Alguma poesia. São Paulo: Nova Cultural, 1988.

ANDRADE, Carlos Drummond de. A paixão medida. 2.ed. Rio de Janeiro: Record, 1994.

ANDRADE, Mário de. O artista e o artesão. In: ANDRADE, Mário de. O baile das quatro artes. São Paulo: Martins; Brasília: INL, 1975.

ARISTÓTELES. Arte poética. Trad.: Assis Brasil. São Paulo: Tecnoprint, 1986.

CANDIDO, Antonio. Inquietudes na poesia de Drummond. In: CANDIDO, Antonio. Vários escritos. São Paulo: Duas cidades, 2004. 
JOSEF, Bella. A questão da crítica e a crítica em questão.

Revista Tempo Brasileiro - Função da crítica, Rio de Janeiro, n. 60, jan./mar., 1980. https://doi.org/10.11606/t.8.2017.tde31072017-121336

LINHARES FILHO. O amor e outros aspectos em Drummond. Fortaleza: Editora UFC, 2002.

PAZ, Octávio. Os signos em rotação. In: PAZ, Octávio.

Signos em rotação. São Paulo: Perspectiva, 1976. https://doi. org/10.2307/j.ctt169zstb.11

PLATÃO. Livros III, IX, X. In: PLATÃO. A República. Trad: Eurico Corvisieri. São Paulo: Nova Cultural, 1997.

SANT'ANNA, Affonso Romano de. Drummond, o gauche no tempo. Rio de Janeiro: Lia, INL, 1972.

Recebido em: 15/11/2017.

Aprovado em: 25/01/2019.

Publicado em: 21/06/2019.

\section{Autor:}

José Wellington Dias Soares

Doutor em História (UFMG). Professor Adjunto do Curso de Letras da Universidade Estadual do Ceará, Fortaleza, CE, Brasil.

Orcid: https://orcid.org/0000-0002-1497-8996

E-mail: wellington.soares@uece.br

Endereço: Universidade Estadual do Ceará,

Faculdade de Educação, Ciências e Letras do Sertão Central

Rua José de Queiroz Pessoa, 2554 - Centro

63900-000, Quixadá, CE, Brasil 